\title{
The Effect of Total Mixture Concentrate Based on Tofu Waste Silage as Feed on Performance of Lambs
}

\author{
Yafri Hazbi, Zaenal Bachruddin*, Nafiatul Umami and Lies Mira Yusiati \\ ${ }^{1}$ Faculty of Animal Science, Universitas Gadjah Mada, Yogyakarta, Indonesia \\ *Corresponding author.Email: bachrudin@ugm.ac.id
}

\begin{abstract}
This study to identify the benefits of total mixture concentrate based on tofu waste silage (TMC-TWS) as ratio containing lactic acid bacteria on the performance. Fifteen weaning lambs (2-3 months old) randomly divided into two treatment groups, treatment group I (TI) fed with TMC-TWS as ration and treatment group II (TII) fed with TMC-TWS fresh (without silage fermentation). The performance evaluated on days 0,15 , and 30 body weight. Meanwhile, blood sampling and feces were made on the $30^{\text {th }}$ day to get an analysis on the blood profile (erythrocytes ( $\mathrm{mill} / \mathrm{ml}$ ), hemoglobin $(\mathrm{g} / \mathrm{dL})$, packed cell volume (\%), and leukocytes $(\mathrm{mill} / \mathrm{ml}))$ and the number of worm eggs in feces. The results of this study shownosignificant difference between the effect of different feed on the blood profile (erythrocytes (mill/ml), hemoglobin $(\mathrm{g} / \mathrm{dL})$, packed cell volume $(\%)$, as well as the number of worm eggs in the feces. The data were analyzed using a factorial completely randomized design. However, the results show significant difference $(\mathrm{P}<0.05)$ treatment group based on sex on gain, feed conversion rate and the number of erythrocytes.
\end{abstract}

Keywords: Blood profile, lambs, total mixture concentrate, silage.

\section{INTRODUCTION}

A feed is a crucial factor in meeting animal nutrient requirements. Ruminants require forage and concentrate both quantity and quality as a source of nutrients. The use of cheap feed which has proper nutrients is an effort to improve the efficiency of animal productivity. Tofu waste is a type of feed that is already well-known as animal feed. It also contains proper nutrients. It is widely available and has a low price, and those become the reason for the use of tofu waste as animal feeding. One of the efforts is through tofu waste-based silage processing. It is the making of tofu waste-based fermentation using lactic acid bacteria (LAB) starter cultures. The function of the LAB as probiotics can be used as an additive which affects the improvement of lamb performance.

Tofu waste silage is given to lamb after its weaning age. The gastrointestinal tract of lamb after weaning has not yet well-developed so that it is expected to show the effects of LAB to the lamb. This study aims to find out about the roles of LAB, which has the potential to be probiotics, in tofu waste-based fermentation on the performance of the probiotics in ruminants. The observation indicators include the growth of the animal, and blood profile.
The fermentation of concentrate is an effort to process concentrate through the addition of lactic acid bacterial inoculants in order to extend its shelf life. In the fermentation process, bacteria break down cellulose and hemicellulose into simple sugars. Other bacteria are breaking down the simple sugars into acetic, lactic, or butyric acids. The fermentation process produces lactic acid and prevents food from spoilage organisms (1). Tofu waste it has a weakness as a feed ingredient, namely highwater content and coarse-fiber content. This waste can get spoiled in less than a week. Fresh tofu waste has high water content, resulting in a relatively short shelf life (2). The aims of this study are expected to provide scientific information on the utilization of TMC-TWS as ration containing lactic acid bacteria which may function as animal probiotics in the growth of lamb. 


\section{MATERIAL AND METHODS}

\subsection{Materials}

This research used 15 lambs with an average age of three months. The animals consisted of eight females and seven males. Treatment was done to four groups, namely four female and male lambs as two control groups, and four female and three male lambs were given TMC-TWS. The rations given were in the form of forage and concentrates. The feed treatments included the addition of concentrate in the form of TMC-TWS and non-fermented concentrate (fresh). The water was from a well-given ad libitum.

\subsection{Methods}

\subsubsection{Feed production}

The making of TMC-TWS feed used the composition as seen in Table 1. Lactobacillus plantarum was used as starter bacteria. Bacteria L. Plantarum was obtained from the collection of Animal Biochemistry Laboratory, Faculty of Animal Science, Univerisitas Gadjah Mada. The starter was obtained from the previous TMC-TWS which had become silage. The ingredients were mixed until homogeneous, then put in clear plastic and stored in a drum. The storage was under the anaerobic condition for 21 days. Fresh concentrate feed was made daily and according to the composition in Table 1.

\subsubsection{Threatment and experimental animals}

Sheep were given anthelmintic before treatment. In the first week, the sheep underwent feeding adjustment.
The sheep were given concentrates and forage feed. The feeding was $10 \%$ of the body weight; consisting of $30 \%$ concentrate and $70 \%$ forage of the $10 \%$ weight of the lambs. The sheep were divided into four groups with different types of feed treatments. The ewe (female sheep) group is a control group and labeled as KIIA, a ram (male sheep) group also is a control group and

Table 1. Concentrate composition

\begin{tabular}{|l|l|l|}
\hline Feed Ingredients & $\begin{array}{l}\text { (TMC-TWS } \\
\%)(T 2)\end{array}$ & $\begin{array}{l}\text { Control (\%) } \\
(\mathrm{T} 1)\end{array}$ \\
\hline Feed composition (\%) & & \\
\hline Tofu waste & 50.26 & 51.99 \\
\hline Rice bran & 29.33 & 30.32 \\
\hline Wheat bran & 12.56 & 12.99 \\
\hline Molases & 4.18 & 4.34 \\
\hline Vitamin & 0.16 & 0.18 \\
\hline Mineral & 0.16 & 0.18 \\
\hline Starter L. Plantarum & 3.35 & - \\
\hline Total & 100 & 100 \\
\hline
\end{tabular}

labeled as KIIB, a group of ewes given TMC-TWS is labeled as KIA, and a group of rams given TMC-TWS is labeled as KIB. Drinking water was given ad libitum.

\subsubsection{Data collection}

The data were obtained from feed consumption, daily weight gain and blood collection. The data were analyzed using a factorial completely randomized design.

Table 2. Dry matter intake of sheep fed by total mixture concentrate silage based on tofu waste

\begin{tabular}{|l|l|l|l|}
\hline Dry matter intake (\%BB) & Control & TMR-TWS & Average $^{\text {ns }}$ \\
\hline Ram & $2.56 \pm 0.89$ & $2.84 \pm 0.36$ & $2.70 \pm 0.63$ \\
\hline Ewe & $2.94 \pm 0.61$ & $3.07 \pm 0.88$ & $3.00 \pm 0.76$ \\
\hline Average $^{\mathrm{ns}}$ & $2.75 \pm 0.75$ & $2.96 \pm 0.62$ & \\
\hline
\end{tabular}

Table 3. Growth and feed conversion of sheep fed by total mixture concentrate silage based on tofu waste

\begin{tabular}{|l|l|l|l|}
\hline Variables & Control & TMC-TWS & Average $^{\text {ns }}$ \\
\hline ADG $(g)$ & & & \\
\hline Ram & $113.21 \pm 6.97$ & $121.69 \pm 15.73$ & $117 \pm 11.35$ \\
\hline Ewe & $87.50 \pm 17.99$ & $67.41 \pm 26.15$ & $77.46 \pm 22.07$ \\
\hline Average $^{\text {ns }}$ & $100.36 \pm 12.48$ & $94.55 \pm 20.94$ & \\
\hline Conversion $^{\text {Ram }}$ & & & \\
\hline Ewe $^{\text {Average }}{ }^{\text {ns }}$ & $3.97 \pm 0.24$ & $4.23 \pm 0.62$ & $4.10 \pm 0.43$ \\
\hline & $6.10 \pm 1.13$ & $7.26 \pm 2.61$ & $6.68 \pm 1.87$ \\
\hline
\end{tabular}




\section{RESULTS AND DISCUSSION}

\subsection{Feed consumption}

The feed consumption (dry matter intake) of sheep fed by total mixture concentrate silage based on tofu waste was showed in Table 2. The highest average percentage of dry matter consumption is in the treatment group of ewes TMC-TWS of $3.07 \pm 0.88 \%$. The lowest average of dry matter consumption is in the control group of rams by $2.56 \pm 0.89 \%$. The ratio of dry matter consumption of $3.16 \%$ with a range of 2.31 to $3.55 \%$ (3). Sheep need dry matter intake around 3.0 to $4.0 \%$ (4). The dry matter consumption has no significant difference in the percentage of dry matter consumption.

The highest average percentage of dry matter consumption is in the treatment group of ewes TMCTWS of $3.07 \pm 0.88 \%$. The lowest average of dry matter consumption is in the control group of rams by $2.56 \pm 0.89 \%$. The ratio of dry matter consumption of $3.16 \%$ with a range of 2.31 to $3.55 \%$ (5). The dry matter consumption has no significant difference in the

Table 4. Blood profile of sheep fed by total mixture concentrate silage based on tofu waste

\begin{tabular}{|c|c|c|c|c|}
\hline Blood profile & Control & TMC-TWS & Avg ns & Normal Avg \\
\hline \multicolumn{5}{|c|}{ Erythrocytes $\left(\times 10^{6} / \mathrm{mm}^{3}\right)$} \\
\hline Ram & $8.59 \pm 1.02$ & $7.64 \pm 0.72$ & $8.12 \pm 0.87$ & $9.50-11.1$ \\
\hline Ewe & $9.75 \pm 1.04$ & $9.60 \pm 1.28$ & $9.68 \pm 1.16$ & $10.3-12.9$ \\
\hline Average* & $9.17 \pm 1.03$ & $8.62 \pm 1.00$ & & \\
\hline \multicolumn{5}{|c|}{ Hemogobin $(\mathrm{g} / \mathrm{dl})$} \\
\hline Ram & $12.43 \pm 1.57$ & $11.05 \pm 1.16$ & $11.74 \pm 1.37$ & $10.0-11.8$ \\
\hline Ewe & $11.75 \pm 1.28$ & $11.93 \pm 1.05$ & $11.84 \pm 1.17$ & $10.7-12.2$ \\
\hline Average ${ }^{\mathrm{ns}}$ & $12.09 \pm 1.43$ & $11.49 \pm 1.11$ & & \\
\hline \multicolumn{5}{|l|}{ PCV (\%) } \\
\hline Ram & $31.66 \pm 1.52$ & $29.25 \pm 2.62$ & $30.46 \pm 2.07$ & 29.9-33.6 \\
\hline Ewe & $30.25 \pm 2.06$ & $31.25 \pm 2.22$ & $30.75 \pm 2.14$ & $31.5-36.7$ \\
\hline Average $^{\mathrm{ns}}$ & $30.96 \pm 1.79$ & $30.25 \pm 2.42$ & & \\
\hline \multicolumn{5}{|c|}{ Leukocyte $\left(\times 10^{3} / \mathrm{mm}^{3}\right)$} \\
\hline Ram & $5.80 \pm 2.99$ & $7.05 \pm 1.38$ & $6.43 \pm 2.19$ & $5.30-10.3$ \\
\hline Ewe & $8.88 \pm 1.87$ & $10.50 \pm 3.66$ & $9.69 \pm 2.77$ & $4.90-9.70$ \\
\hline Average $^{\text {ns }}$ & $7.34 \pm 2.43$ & $8.78 \pm 2.52$ & & \\
\hline \multicolumn{5}{|c|}{ Lymphocytes $\left(\times 10^{3} / \mathrm{mm}^{3}\right.$ ) } \\
\hline Ram & $54.75 \pm 12.15$ & $55.50 \pm 8.23$ & $55.13 \pm 10.19$ & $46.9-66.9$ \\
\hline Male & $49.50 \pm 22.55$ & $56.75 \pm 11.27$ & $53.13 \pm 17.41$ & 48.9-75.1 \\
\hline Average $^{\text {ns }}$ & $52.13 \pm 17.35$ & $56.13 \pm 9.75$ & & \\
\hline \multicolumn{5}{|c|}{ Neutrophiles $\left(\times 10^{3} / \mathrm{mm}^{3}\right)$} \\
\hline Ram & $40.00 \pm 11.17$ & $37.25 \pm 10.21$ & $38.63 \pm 10.69$ & $33.2-48.2$ \\
\hline Ewe & $39.75 \pm 18.81$ & $34.75 \pm 12.50$ & $37.25 \pm 15.66$ & $14.5-41.5$ \\
\hline Average $^{\text {ns }}$ & $39.88 \pm 14.99$ & $36.00 \pm 11.36$ & & \\
\hline \multicolumn{5}{|c|}{ Eosinophiles $\left(\times 10^{3} / \mathrm{mm}^{3}\right)$} \\
\hline Ram & $1.50 \pm 0.58$ & $3.50 \pm 1.30$ & $2.50 \pm 0.94$ & $0.90-4.10$ \\
\hline Ewe & $4.50 \pm 3.32$ & $2.75 \pm 2.36$ & $3.63 \pm 2.84$ & $3.60-12.4$ \\
\hline Average & $3.00 \pm 1.95$ & $3.13 \pm 1.97$ & & \\
\hline \multicolumn{5}{|c|}{ Monocytes $\left(\times 10^{3} / \mathrm{mm}^{3}\right)$} \\
\hline Ram & $3.75 \pm 0.96$ & $3.75 \pm 1.71$ & $1.00 \pm 1.34$ & $1.00-8.00$ \\
\hline Ewe & $6.25 \pm 5.85$ & $5.75 \pm 2.87$ & $6.00 \pm 4.36$ & $0.72-3.28$ \\
\hline Average $^{\text {ns }}$ & $5.00 \pm 3.41$ & $4.75 \pm 2.29$ & & \\
\hline
\end{tabular}

ns: non significant 
percentage of dry matter consumption based on the sex and types of feeding treatments. The amount of dry matter consumption is influenced by several variables, including palatability, the available amount of feed, chemical composition, and quality of feed ingredients. The consumption of dry matter is also influenced by the size of the animal's body. The ability of an animal to consume feed is heavily influenced by body weight, age, sex, environment, health, and quality of feed (6).

\subsection{Body weight gain}

The body weight gain and feed convertion ratio of sheep fed by total mixture concentrate silage based on tofu waste was showed in Table 3. The ewe group with TMC-TWS treatment was demonstrated the highest dry matter intake conversion ratio, i.e., 7.26 \pm 2.61 . The lowest dry matter intake conversion ratio is in the ram group with TMC-TWS treatment, i.e., 3.97 \pm 0.24 . Sex differenced show significant differences in the growth of body weight $(\mathrm{P}<0.05)$. The ratio of feed conversion of 6.98 to 25.13 with an average of $16.46,15.18$, and 14.81 (3). Meanwhile, the ratio of feed conversion in the research conducted by (7) ranges between 10.06 until 12.72 .

Sex differences showed significant differences in feed conversion $(\mathrm{P}<0.05)$. The results show that ram has a higher dry matter conversion ratio than ewe group. Sex and activity also affect the level of consumption (8). The ratio of feed conversion, which is good for the growth of sheep is equal to four (9). The ram groups both in control and treatment with TMC-TWS have a good conversion. The ewe groups both in control and treatment with TMCTWS have a conversion ratio higher than four. The feed conversion of ruminants is influenced by the quality of rations, digestibility value and efficiency in the use of nutrients in the metabolic processes in animals' body tissues. Better quality of the rations consumed by animals will lead to higher weight gain and more efficient use of the rations. High or low conversion ratio describes feed efficiency (10).

Different treatment types of feed provision do not show any significant result in the growth of body weight per day. Significant differences $(\mathrm{P}<0.05)$ in weight gain were found in the relationship of weight with sex. The average weight gain of ram is higher than that of the ewes. The score of weight gain in all the treatment groups shows that TMC-TWS treatment results in a higher weight gain score than that of the control groups. The highest score of weight gain was showed by the ram group with TMC-TWS treatment, was $121.69 \pm 15.73$ $\mathrm{g} /$ day. The lowest weight gain was found in the ewe group with TMC-TWS treatment was $67.41 \pm 26.15 \mathrm{~g} / \mathrm{day}$. The results of this research show almost similar results to that of (11) who reported of ADG of sheep was 61.11, $81.95,95.83$, and $102.77 \mathrm{~g} / \mathrm{day}$. One of the factors influenced weight gain is feed consumption. The high of feed consumption and digestibility will result a higher body weight gain because more nutrients were absorbed (12).

\subsection{Blood profile}

The blood profile of sheep fed by total mixture concentrate silage based on tofu waste was showed in Table 4. The status of blood is a manifestation of the physiological condition of the body which is closely related to the level of fitness because functional blood status will be able to support other physiological processes (13). Based on Table 4 on the blood hematology of the overall treatment results, it can be concluded that the results do not show any significant differences between the control group and groups with TMC-TWS treatment on rams and ewes. The number of erythrocytes on rams ranges from 8 to $15 \times 10^{6} / \mathrm{mm}^{3}$ with an average of $12 \times 10^{6} / \mathrm{mm}^{3}$ while that of ewes ranges from 10.3 to $12.9 \times 10^{6} / \mathrm{mm}^{3}$ (13). All the treatment sheep show reasonable condition. The standard number of red blood cells on local sheep ranges from 6-9 million $/ \mathrm{mm}^{3}$ (14). The number of erythrocytes concerning the sex of sheep shows significant differences $(\mathrm{P}<0.05)$. The number of ewes' erythrocytes is higher than the number of rams' erythrocytes (15). Differences in the number of erythrocytes in the control groups and treatment groups with TMC-TWS can be caused by many factors. The number of erythrocytes varies depending on breeds, activity, age, sex, altitude, and other factors (16).

Table 4 showed that there is no significant difference in the level of hemoglobin in each treatment group. All the sheep groups show a normal level of hemoglobin. The level of hemoglobin on ram ranges from 10.0 to $11.8 \mathrm{~g} / \mathrm{dl}$ while that of ewes ranges from 10.7 to $12.2 \mathrm{~g} / \mathrm{dl}$ (15). The biosynthesis of $\mathrm{Hb}$ starts in erythrocytes and keeps occurring in the further stages of the development of red blood cells. As long as the nucleus is still in the red blood cell, hemoglobin formation continues (17). The levels of hemoglobin in the blood are influenced by several factors, such as feed, season, activity of the body, erythrocyte damages, and blood handling during the inspection (18).

Hematocrit or packed cell volume (PCV) is the percentage of red blood cells in $100 \mathrm{ml}$ of blood. PCV is used to count the amount of blood and to check the number of red blood cells, although hematocrit is not the right measurement of blood volume. Statistical analysis does not show any significant differences in all treatments and sexes. The PCV of the ram group with STCK-at and the ewe control group in Table 7 are below the normal range. The PCV in ram ranges from 29.9 to $33.6 \%$ and that in ewes ranges from 31.5 to $36.7 \%$ (18). Dehydrated animals may experience fluid loss from all the body compartments then causes a decrease in plasma volume, resulting in an increased hematocrit value called hemoconcentration (19).

The leukocytes of all sheep treatments show a normal state. The eosinophil count of rams ranges from 0.90 to $4.10 \times 10^{3} / \mathrm{mm}^{3}$ and that of ewes ranges from 3.60 to $12.4 \times 10^{3} / \mathrm{mm}^{3}(15)$. This situation shows that there is no process of infection from any disease. An increase in the number of white blood cells is generally a sign of infection. White blood cells are not functional and only 
transported when needed (16). Other differential counts such as monocytes, lymphocytes, and neutrophils show no significant differences among all treatments.

Feeding TMC-TWS, which contains lactic acid bacteria which are expected to be a probiotic for animals, has not shown any significant difference in the treatments. Lactic acid bacteria are expected to improve the absorption of nutrients from the feed and shown in the blood profile.

\section{CONCLUSION}

The feed of total mixture concentrate silage based on tofu waste can extend the utilization of tofu waste and can become feed for sheep. The consumption of dry matter weight of TMC-TWS with the control treatment shows no effect on weight gain and blood profile.

\section{REFERENCES}

[1] Widyastuti, Y. 2008. Fermentasi silase dan manfaat probiotik silase bagi ruminansia. Jurnal Media Peternakan 31(3): 225-232.

[2] Wahyuni, S. 2003. Karakteristik Nutrisi Ampas Tahu yang Dikeringkan sebagai Pakan Domba. Tesis Magister Ilmu Ternak, Universitas Diponegoro, Semarang.

[3] Budisatria, I. G. S., 1998.Pengaruh penambahan urea dan molases dalam ransum terhadap penampilan ternak domba lokal jantan. Bulletin Peternakan 22 (4): 179-186.

[4] Fahmi, Taemi., S. Tedi, E. Sujitno. 2015. Petunjuk Teknis Manajemen Pemeliharaan Ternak Domba. Balai Pengkajian Teknologi Pertanian Jawa Barat.

[5] Gimenez., Diego M. 1994. Nutrient Requirements of Sheep and Goats.Alabama A \& M and Auburn Universities. The United States.

[6] Parakkasi, A. 1999. Ilmu Nutrisi dan Makanan Ternak Ruminan. Cetakan Pertama Penerbit UP, Jakarta.

[7] Purbowati, E. 1996.Kinerja Domba yang Digemukkan secara Feedlot dengan Aras Konsentrat dan Pakan Dasar Berbeda.Thesis. Program Pasca Sarjana, Universitas Gadjah Mada.

[8] Siregar.1994. Ransum Ternak Ruminansia. Penebar Swadaya, Jakarta.

[9] National Research Council. 1981. Nutrien Requirement of Domestic Goat: Angora, Dairy, and Meat Goat in Temperate and Tropical Countries. National Academy Press, Washington.
[10] Gusmanizar, N. 1999.Pengaruh penggunaan kulit biji coklat (Theobromacacao $L$ ) dalam ransum terhadap performa ayam broiler. Jurnal Peternakan Universitas Andalas 5(2): 18-27.

[11] Munier, F.F., D. Bulo., Saidah., Syafruddin., R. Boy., N. F. Femmi dan S. Husain. 2004. Pertambahan bobot badan domba ekor gemuk (deg) yang dipelihara secara intensif. Seminar Nasional Teknologi Peternakan dan Veteriner 2004. Bogor: 341-347.

[12] Rasyid, H. 2009. Performa produksi kelinci lokal jantan pada pemberian rumput lapang dan berbagai level ampas tahu. Skripsi. Fakultas Peternakan. Institut Pertanian Bogor, Bogor.

[13] Ernianingsih, I., dan T. R. Saraswati. 2006. Penambahan limbah padat kunyit (Curcuma domestica) pada ransum ayam dan pengaruhnya terhadap status darah dan hepar ayam (Gallus $s p$ ). Buletin Anatomi dan Fisiologi 14 (2):1-6.

[14] Astuti, D. A., R. E. Kastuti, Marwah and Yani. 2009. Status nutrien dan gambaran darah domba lokal yang dipelihara di hutan Pendidikan Gunung Walat, Sukabumi. Seminar Nasional Teknologi Peternakan dan Veteriner 2006. Bogor. 399-404.

[15] Mitruska, B. M. and Rawnsley, H.M. 1981. Clinical Biochemical and Hemathological References Value in Normal Experimental Animals and Human. 2nd ed. Year Book Publisher Inc., Chicago.

[16] Soeharsono, 2010. Fisiologi Ternak. Fenomena dan Nomena Dasar dari Fungsi serta Interaksi Organ pada Hewan.WidyaPadjadjaran, Bandung.

[17] Suwandi. 2002. Manfaat pemeriksaan gambaran darah umum. Pada ternak ruminansia. Temu Teknis Fungsional Non Peneliti 2002. Bogor :133-139.

[18] Andriyanto, Y. S. Rahmadani, A. S. Satyaningtijas, A. Sutisna. 2010. Gambaran hematologi domba selama transportasi: peran multivitamin dan meniran. Jurnal Ilmu Pertanian Indonesia 15 (3):172-177.

[19] Robergs, R. 1997. Exercise Physiology. Mosby Year Book, Inc., Missouri, USA 